REFLECTIONS:

NEUROLOGY AND

THE HUMANITIES

\title{
Chief complaint
}

Section Editor

Anne W. McCammon,

MD, FAAN

Ariel Ludwig, MPH

Correspondence to

Dr. Ludwig:

arludwig@utmb.edu
Lights.

A miasma of translucent neon lights.

"It's not so much a complaint,"

she folds her fragile hands;

"as a beautiful concern."

They are the geometric patterns

and the delicate ribbed glow around her visible world,

almost worth their pain.

"At first I thought I was going mad,"

she gives a bashful half grin.

"But it was a lovely madness,

it was like I woke up one day with a gift.

They keep me company, in a way."

Her eyes dart down.

The doctor makes notes until she is done.

"Migraines,"

he says,

"very common."

He looks at his notes.

"I cannot leave you with the lights, and not the pain."

"It's your choice, of course." 


\section{Neurology}

\section{Chief complaint}

Ariel Ludwig

Neurology 2014;83;1876

DOI 10.1212/WNL.0000000000000989

This information is current as of November 10, 2014

\section{Updated Information \& Services}

\section{Subspecialty Collections}

Permissions \& Licensing

Reprints including high resolution figures, can be found at: http://n.neurology.org/content/83/20/1876.full

This article, along with others on similar topics, appears in the following collection(s):

All Neuro-ophthalmology

http://n.neurology.org/cgi/collection/all_neuroophthalmology

Autoimmune diseases

http://n.neurology.org/cgi/collection/autoimmune_diseases

Migraine

http://n.neurology.org/cgi/collection/migraine

MRI

http://n.neurology.org/cgi/collection/mri

PET

http://n.neurology.org/cgi/collection/pet

Information about reproducing this article in parts (figures,tables) or in its entirety can be found online at:

http://www.neurology.org/about/about_the_journal\#permissions

Information about ordering reprints can be found online:

http://n.neurology.org/subscribers/advertise

Neurology ${ }^{\circledR}$ is the official journal of the American Academy of Neurology. Published continuously since 1951, it is now a weekly with 48 issues per year. Copyright @ 2014 American Academy of Neurology. All rights reserved. Print ISSN: 0028-3878. Online ISSN: 1526-632X.

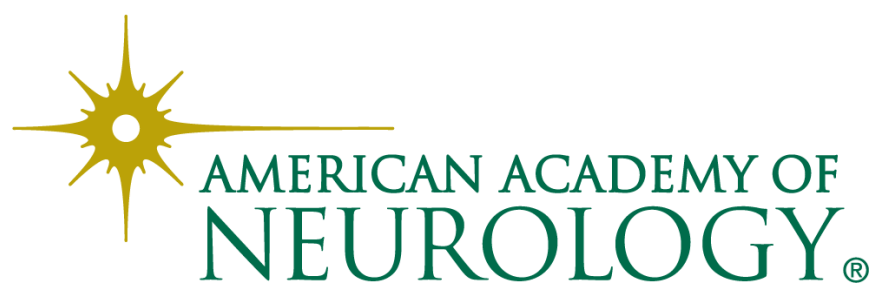

